\title{
Quantification and Characterization of Solid Waste in Alkalakla Administrative Unit, Khartoum State - Sudan
}

\author{
Ahmed Abdelgadir Mohamed Elzaki ${ }^{1,2^{*}}$ and Basheir Mohamed Elhassan ${ }^{3}$ \\ ${ }^{1}$ Department of Environmental Health, Faculty of Public \& Environmental Health, University of Khartoum, Sudan \\ ${ }^{2}$ Department of Public Health, College of Health Sciences, Saudi Electronic University, Saudi Arabia \\ ${ }^{3}$ Department of Chemical Engineering, Faculty of Engineering, University of Khartoum, Sudan
}

*Corresponding author: Ahmed Abdelgadir Mohamed Elzaki, Department of Environmental Health, Faculty of Public \& Environmental Health, University of Khartoum, Sudan, Tel: +00249912820940; E-mail: ahmedgader772@yahoo.com

Received date: March 07, 2019; Accepted date: March 29, 2019; Published date: April 05, 2019

Copyright: (c) 2018 Mohamed Elzaki AA, et al. This is an open access article distributed under the terms of the Creative Commons Attribution License, which permits unrestricted use, distribution and reproduction in any medium, provided the original author and source are credited.

\begin{abstract}
Solid waste generation is an outcome of human activities, poor solid waste management lead to serious public health problems. Quantification and characterization of solid waste components consider an important step in solid waste management procedures. A cross-sectional descriptive study was conducted in Alkalakla Administrative Unit to determine solid waste per capita generation rate and identify solid waste compositions. Considering seasonal variations and socio-economic class, World Health Organization (WHO) and California Integrated Waste Management Board (CIWMB) procedures for solid waste survey were adopted in sampling procedure and solid waste segregation. Data were collected and analyzed three times in 2013 (January, May, and August). The average weight of solid waste generated in Alkalakla Administrative Unit, taking into account all three seasons, was $0.401 \mathrm{~kg} /$ capita/day, and accordingly estimated annual amount of solid waste was (36241.6 ton). There was negative moderate correlation between family size and solid waste per capita generation rate $(r=-0.449, p$ value $<0.001)$. Analysis of solid waste component shows that food remains accounts for the largest proportion (37\%), followed by earth materials $(20.5 \%)$ and plastic $(13 \%) .3 .77 \%$ of solid waste was hazardous materials. Ash and dung represented the lowest percentage $(0.31 \%)$ and $(0.11 \%)$ respectively. The average of solid waste per capita generation rate across the seasons and neighborhoods, were similar to the average weight estimated by Eastern Mediterranean Regional Office (EMRO), while it had significant differences from the average estimated by Khartoum State Cleaning Corporation. Statistically there were seasonal variations in solid waste generation; however there were no significant differences between neighborhoods. Study findings have significant economic prospective in solid waste management particular high percentages of organic components and low density of solid waste.
\end{abstract}

Keywords: Generation rate; Waste characterization; Seasonal variation; Waste composition; Segregation

\section{Introduction}

Daily human activities always generated solid waste, which became serious public health problems with poor management [1-4]. Solid waste materials are a nuisance and may cause adverse impacts in human health and the environment [5-7]. Geographic location, climate, rapid urbanization, lifestyle, demographics and socioeconomic factors are the main determinants of solid waste compositions and amount [2,5,8-12]. Income level, household size, and education status are highly cited as factors affecting solid waste generation rates. Yet, the effects of those may not be at the same level in different locations such as countries, cities, regions, etc. [13]. Solid waste generation rate is reduced when the population of the area increases [14].

Poor solid waste management practices have a serious threat to health and environment because it may lead to: air, soil and water pollution [15-17], unfortunately only $60 \%$ of the waste generated in developing countries is actually collected and disposed properly [18]. The collection and treatment of municipal solid waste are usually insufficient due to a lack of complete information on the amount of municipal solid waste discards [19].
A reliable estimation of the solid waste quantity in the city is very important for proper solid waste planning and management [20]. Data on waste composition, production, and recycling are essential for designing routes of collection systems, determining placements for bins, managing collection crews, and select appropriate solid waste disposal options [5,21-25], and it's crucial if alternative waste management schemes should be developed, for example if material recycling or biological treatment should be considered [26]. Several studies on characterization of solid waste were conducted in developing countries particular sub-Saharan Africa to determine their physical, chemical and thermal properties [27]; however accurate and updated data regarding solid waste are not available in most Sudanese cities and towns due to lacking of technical and financial resources.

Objectives: This study was focused on determination of solid waste composition and per capita generation rate in Alkalakla Administrative Unit. The specific objectives were; to estimate solid waste generation rate for different sources, to determine main solid waste components, to identify solid waste density, and to identify the differences between neighborhoods, sectors and seasons in respect to solid waste generation rate, compositions and density. 


\section{Materials and Methods}

\section{Study area}

Alkalakla Administrative Unit is one of Gabal Awllia locality in Khartoum State, it is located in the east bank of White Nile bordered by Khartoum locality from north, White Nile from west, Alnil Alabid Administrative Unit from south and Al nasar Administrative Unit from east. Its total area is about $155 \mathrm{~km}^{2}$. There are thirty six neighborhoods with about 38079 households in residential areas with various socio-economics grade levels total population are 245462 people, represent $5 \%$ of Khartoum State population according to Sudan fifth census conducted in April 2008. Water, electricity, education, medical services, waste management, transportations, and other civil services are provided by locality and other government agencies.

Waste management provided by Gabal Awllia locality Cleaning Corporation. According to cleaning corporation polices Alkalakla administrative unit was divided into two residential sectors (West and East), in addition to Al lafa market sector, every one of these sectors has administration sub office to manage solid waste operations and activities.

Study variables: Solid waste generation rate, solid waste compositions, and solid waste volumes and density.

Sample frame: All 63 neighborhoods in the study area were set in a list with an equal chance in selection procedure.

\section{Methods}

Stratified random sample technique was used. According to administrative considerations the study area was divided into two sectors, the west sector was more homogenous so all 40 neighborhoods were listed, and Al goba Shamal was selected randomly to represent the west sector. The east sector has 23 neighborhoods with various socioeconomic statuses, hence it's representative by two neighborhoods and accordingly $\mathrm{Abu}$ adam, and $\mathrm{Al}$ wohda were selected randomly to represent the sector.

According to California Integrated Waste Management Board (CIWMB) method [28], thirty households from each administration sector were sampled to examine the characteristics of solid waste generated from residential neighborhoods. Total sampled households were 60 but according to reference solid waste sampling procedure recommended by (WHO) [25], solid waste samples were collected for eight consecutive days from all selected households, so about 199 samples in Winter, 198 samples in Summer, and 195 samples in Autumn were collected from west sector and 173 samples in Winter, 191 samples in Summer, and 180 samples in Autumn were collected from east sector. The total samples weighed and sorted were 372,389 and 375 in winter, summer, and autumn respectively. Data were collected in January, May, and August 2013.

\section{Samples collection procedure}

All selected households were contacted by well-trained data collectors 2 days before starting samples collection, eight labeled plastic bags were provided to every targeted household to store their generated solid waste on it, adult member from each household was asked to participate in the study then he/she asked to answer the questions of study questionnaire and give him/her the structures regarding the storage and handling of their solid waste samples and they were advised to put all their generated solid waste in one plastic bag every day during the study period. Solid waste samples were collected every day at morning $(9-11 \mathrm{am})$ for eight consecutive days, automobile vehicle was used in solid waste samples collection, two well-trained data collectors and one worker participated in collection activities.

\section{Samples Analysis}

Allafa Market lie in the middle of study area thus it was the suitable option to meet the standards requirements of solid waste analysis and sorting site. The sorting site was prepared and arranged to make all sorting and analysis activities easily achieved. Plastic sheet was used to cover ground of sorting site, digital scale was used to weighing solid waste samples, specific plastic container (Waste Pin) was used to measure solid waste volume, plastic bins were used to sort waste categories. Well trained Public Health Officer was responsible of sorting site management and supervision, data registration, and safety measurement implementation, two workers participated in solid waste analysis and manual segregation activities.

The solid waste samples which were collected in first day were excluded to ensure that the analyzed samples were not affected by accumulation of solid waste from the prior days before starting of the study; solid waste samples of seven consecutive days from day 2 to day 8 were analyzed and segregated into its main components. The total solid waste samples which were arrived to sorting site and analyzed were 1136 samples.

Solid waste samples of each neighborhood analyzed separately, every household sample weighed (in $\mathrm{kg}$ ) by digital scale its maximum capacity is $20 \mathrm{~kg}$ and the weight of solid waste registered using reference data sheet, then 15 samples ( $50 \%$ of neighborhood samples) were selected using odd and even number interchangeably, solid waste of fifteen selected samples were mixed together and subjected to volume measurement and registered every day, the solid waste volume and corresponding weight were registered in reference data sheet to calculate solid waste density. After volume measurement solid waste was subjected to manual segregation into main components such as plastic, metals, food remains, papers, glass, ash, and earth materials. Every solid waste category was weighed and registered using reference data sheet. When the team completes the analysis of one neighborhood starting the other, following the rule of first in first analysis, these procedures were repeated for seven days in each season.

According to the information and reports of Sudanese Metrology Corporation, the study was conducted in January to represent winter months and repeated in May and August to represent summer and autumn months respectively. All samples analysis procedure and activities were implemented according to (WHO) guidelines [25]. Standards data sheets which are recommended by (WHO) [25] used to register information regarding solid waste weight, volume and components. Registered data were subjected to Microsoft Excel to calculate the average of solid waste generation rates, average of solid waste densities, and percentages of the main solid waste components. Data were subjected to Statistical Package for Social Science (SPSS) program, Kolmogorov-Smirnov test was used to determine the distribution of the data (test of normality) and accordingly the suitable statistical test for every research variable was selected.

$\mathrm{T}$ test was used to determine the significance of variation between the averages per capita solid waste generation rate of this study and the 
average per capita estimated by World Health Organization Eastern Mediterranean Regional Office (EMRO), (0.5 kg/p.d) and Khartoum State Cleaning Corporation $(0.6 \mathrm{~kg} / \mathrm{p} . \mathrm{d})$. Mann Whetny test was used to determine significance differences in solid waste per capita generation rate and solid waste density between residential sectors. Kruskal test was used to determine significance differences in solid waste per capita generation rate and solid waste density between neighborhoods. Friedman and Wilcoxon tests were used to determine significance differences in solid waste per capita generation rate and solid waste density between the seasons. Spearman's rho was used to determine the correlation between solid waste per capita generation rate and family size.

\section{Results and Discussions}

\begin{tabular}{|c|c|c|c|c|c|c|c|c|c|}
\hline $\begin{array}{l}\text { Neighborhoo } \\
\text { d }\end{array}$ & $\begin{array}{l}\text { Solid waste generation rate } \\
(\mathrm{kg} / \mathrm{Ca} . / \mathrm{d})\end{array}$ & $\begin{array}{l}\text { Solid waste density } \\
\qquad\left(\mathrm{kg} / \mathrm{m}^{3}\right)\end{array}$ & $\begin{array}{c}\text { Food remains } \\
\%\end{array}$ & Earth \% & $\begin{array}{l}\text { Plastic } \\
\%\end{array}$ & $\begin{array}{c}\text { Hazardous } \\
\text { waste } \%\end{array}$ & Dung \% & $\begin{array}{c}\text { Ash } \\
\%\end{array}$ & $\begin{array}{c}\text { Papers } \\
\%\end{array}$ \\
\hline West Sector & 0.438 & 168 & 38.98 & 23.73 & 9.79 & 2.85 & 1.15 & 0 & 5.14 \\
\hline East Sector & 0.392 & 137 & 42.41 & 16.99 & 11.77 & 2.45 & 0.05 & 0.18 & 5.33 \\
\hline Winter (mean) & 0.423 & 153 & 40.7 & 20.36 & 10.78 & 2.65 & 0.6 & 0.09 & 5.24 \\
\hline West Sector & 0.372 & 230 & 39.91 & 24.45 & 9.09 & 2.5 & 0.26 & 0.15 & 4.4 \\
\hline East Sector & 0.364 & 171 & 34.08 & 25.3 & 13.36 & 2.73 & 0.39 & 0.07 & 5.54 \\
\hline $\begin{array}{c}\text { Summer } \\
\text { (mean) }\end{array}$ & 0.368 & 201 & 37 & 24.88 & 11.23 & 2.62 & 0.33 & 0.11 & 4.97 \\
\hline West Sector & 0.418 & 175 & 33.14 & 14.19 & 16.37 & 6 & 0 & 0.25 & 5.06 \\
\hline East Sector & 0.406 & 191 & 33.75 & 18.04 & 17.76 & 6.05 & 0 & 0 & 6.16 \\
\hline $\begin{array}{l}\text { Autumn } \\
\text { (mean) }\end{array}$ & 0.412 & 156 & 33.45 & 16.12 & 17.07 & 6.03 & 0 & 0.13 & 5.61 \\
\hline Alkalakla City & 0.401 & 170 & 37.05 & 20.45 & 13.03 & 3.77 & 0.31 & 0.11 & 5.27 \\
\hline
\end{tabular}

Table 1: Solid waste generation rate, density and composition in Alkalakla Administrative Unit-Khartoum State-Sudan 2013.

United Nation Environmental Programme (UNEP) estimated that the average quantity of municipal solid waste generated throughout Latin America, Asia, and some countries in Africa is in the order of 0.4 $\mathrm{kg} / \mathrm{cap} /$ day, Table 1 revealed that the average solid waste per capita generation rate in Alkalakla administrative unit is $0.401 \mathrm{~kg} / \mathrm{cap} /$ day this is in agree with the literature cited by UNEP [16]; World bank [17]; and Giusti [2] and similar to results of studies conducted by Norbu et al. [29]; Wang et al. [30] however it is contradicted with the average of solid waste per capita generation rate in Khartoum State (0.6-1 kg/cap/day) cited by Abou elseud [1], Moftah et al. [5] obtained different results from their study in Tripoli $(0.66 \mathrm{~kg} /$ person/day). Statistically; the average solid waste per capita generation rate across the seasons and residential sectors in the study area have no significant differences from the average weight estimated by (EMRO) $(0.5 \mathrm{~kg} / \mathrm{cap} /$ day) $(\mathrm{t}=-0.149, \mathrm{df}=179, \mathrm{p}$ value $=0.847)$.

However they have significant differences from the average estimated by Khartoum State Cleaning Corporation $(0.6 \mathrm{~kg} / \mathrm{cap} /$ day $)$ $(\mathrm{t}=-3.629, \mathrm{df}=179, \mathrm{p}$ value $<0.001)$. Income level, household size, and education status are highly cited as factors affecting solid waste generation rates. Yet, the effects of those may not be at the same level in different locations such as countries, cities, regions, etc [13], no significant difference in solid waste average per capita generation rate between residential sectors ( $\mathrm{p}$ value $=0.412$ ) and neighborhoods $(\mathrm{p}$ value $=0.439$ ), this is similar to results reported by Mbande [31]; Passarini et al. [32] all these results disagree with the results of studies conducted worldwide and revealed that socio-economic and geographic factors have a clear effects in solid waste per capita generation rate. Abou elseud [1]; Gomez et al. [10]; Sango [12]; and Wang et al. [30], regarding seasons and climatic conditions there are highly significant differences in solid waste generation rate among all seasons ( $p$ value $<0.001$ ), these are similar to results cited by Gomez et al. [10]; Boer et al. [33]; and Edjabou et al. [34] and disagree with results cited by Mbande [31].

Solid waste generation rate is reduced when the population of the area increases [14], statistical test revealed that there is a negative moderate correlation between family size and solid waste per capita generation rate $(\mathrm{r}=-0.449$, $\mathrm{p}$ value $<0.001)$, this agrees with literature cited by Moftah et al. [5]; Turan et al. [14]; Boer et al. [33]; Yi et al. [35]; Al-Khatib and Arafat [36].

Low income countries have a wet waste density typically between 350 to $550 \mathrm{~kg} / \mathrm{m}^{3}[7,17]$. The opposite is true in the case of solid waste density in Al kalakla administrative unit, Table 1 reveal that the average of solid waste density in residential sectors is very low (170 $\mathrm{kg} / \mathrm{m}^{3}$ ) the study results are similar to the results cited by Japan International Cooperation Agency (JICA) [37] and contradicted with other study results cited by Hazra and Goel [38].

This situation may be due to presence of plastic, papers and other light materials which are increased gradually in solid waste stream in Sudanese urban areas. This fact of low density must be considered in the planning for solid waste management in Alkalakla administrative unit and Khartoum State (Figure 1). 
Citation: Mohamed Elzaki AA, Elhassan BM (2019) Quantification and Characterization of Solid Waste in Alkalakla Administrative Unit,

Page 4 of 6

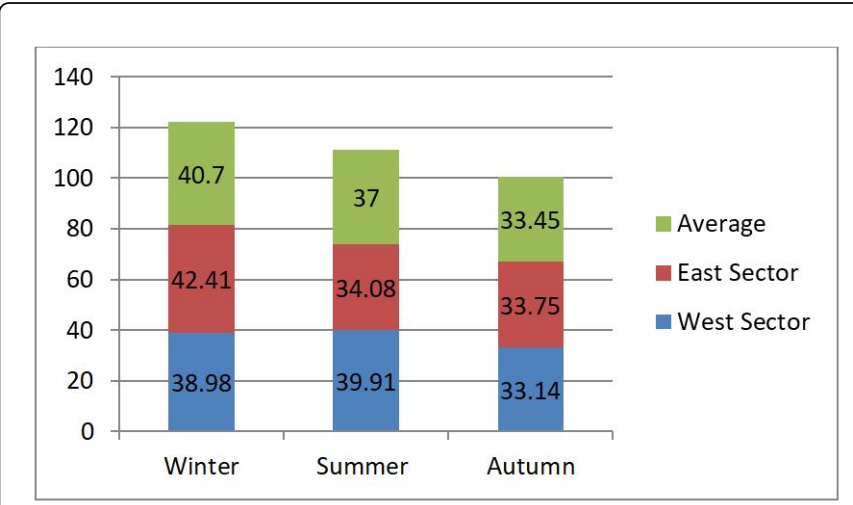

Figure 1: Percentages of food remains distributed by seasons in Alkalakla Administrative Unit 2013.

Always, low and middle income countries have a high percentage of compostable organic matter in the urban waste stream, ranging from $40 \%$ to $85 \%$ of the total [17], however in the same country urban population is generating more organic waste than the rural population [39].

As shown in Figure 2, the most dominant component of municipal solid waste in the western and eastern residential sectors were food waste which accounted for about $(37.34 \%$ and $36.75 \%)$ of municipal solid waste respectively, followed by earth $(20.79 \%, 20.11 \%)$, the third item is plastic (11.75\% and $14.3 \%)$ respectively.

These results mean that most of Alkalakla municipal solid waste is of organic origin, similar findings are also highlighted in several studies in the literature, showing that waste generated in developing countries contains a large percentage of organic materials World Bank [17]; Sakawi [24]; Al-Khatib and Arafat [36]; Hazra and Goel [38]; Abdul Jalil [39]; Moghadam et al. [40]; Moqsud [41]; Lioao et al. [42]; and Parrot et al. [43]. Different results were obtained by Daura et al. [21], they characterized solid waste composition in Kano City and found the percentage of food waste was only $(7.49 \%)$. The high organic content of municipal solid waste in Alkalakla administrative unit provides a window of opportunity for municipal solid waste recycling through composting and/or biogas production via anaerobic digestion.

Compost can be made by aerobic processes as an end product and the volume of organic material in municipal solid waste can be significantly reduced, thus reducing the waste volume that needs to be landfilled. Considering the results of this study in Table 1 the amount of solid waste expected to be removed from residential sector by composting is about (38.32 ton per day).

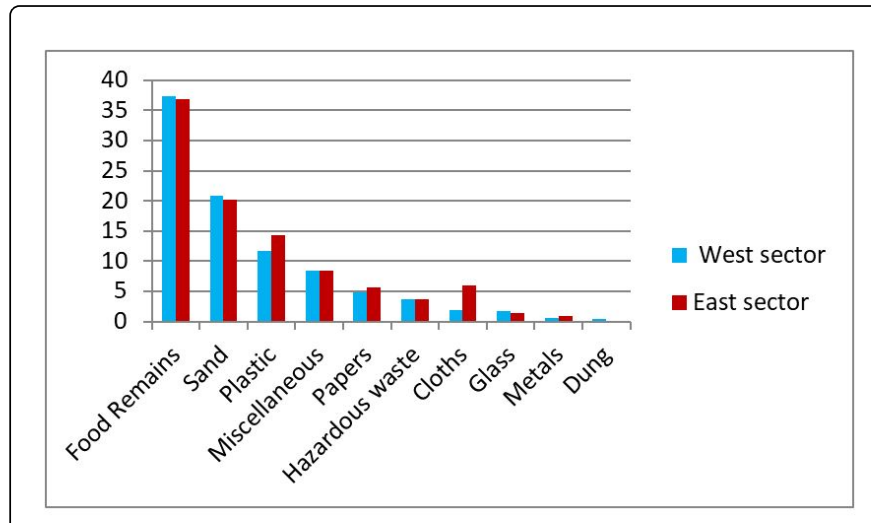

Figure 2: Average percentages of solid waste components classified by residential sectors in Alkalakla administrative unit 2013.

Fifth of solid waste weight in Alkalakla Administrative Unit was earth, this may be due to cleaning behaviors of housewives, this is true particularly when we look to percentages of earth in autumn, although the wet sand is heavy but it represents a lower percent which supports the hypothesis that the housewives collect sand with solid waste in dry seasons and collect only solid waste when the earth is wet. Previous study conducted by Daura et al. [21] in Kano City revealed that the percentages of earth/garbage in solid waste were $(21.67 \%-30.97 \%)$ (Figure 3).

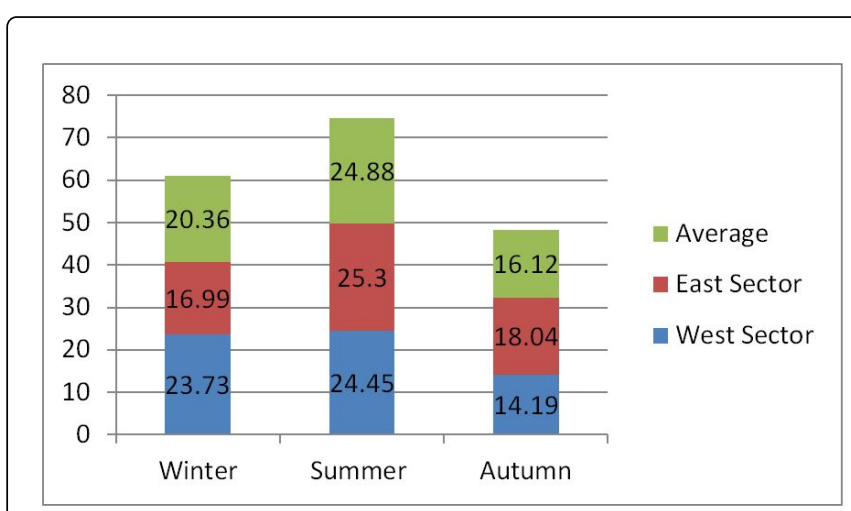

Figure 3: Percentages of earth materials distributed by seasons in Alkalakla Administrative Unit 2013.

Plastic percentages were third important item this may due to the fact that plastic materials were used in packaging. Municipal solid wastes also contain some hazardous substances such as drug residues, expired medicines, chemicals, paints, and household insecticides and their empty containers, used dry batteries, and electrical and electronic equipment [1]. Hazardous materials were observed as a component of solid waste in western and eastern residential sectors (3.78\% and 3.7\%) respectively. Figures 1-3 showed that the fractions of solid waste components were different among seasons and residential sectors; however these differences statistically were not significant.

\section{Conclusion}

The average of solid waste generation rate in Alkalakla Administrative Unit was $(0.40 \mathrm{~kg} / \mathrm{ca} / \mathrm{d})$ and the mean solid waste 
density was very low $\left(170 \mathrm{~kg} / \mathrm{m}^{3}\right)$, the annual amount of generated solid waste was 36241.6 ton. The average of solid waste per capita generation rate across the seasons and neighborhoods, statistically were similar to the average weight estimated by (EMRO) $(0.5 \mathrm{~kg} / \mathrm{cap} /$ day), while it has significant differences from the average estimated by Khartoum State Cleaning Corporation $(0.6 \mathrm{~kg} / \mathrm{cap} /$ day $)$.

There were strong statistical significant differences in solid waste generation rate among all seasons, however no significant differences between residential sectors and neighborhoods. There was a negative moderate correlation between family size and solid waste per capita generation rate. The most dominant components of solid waste in the study area were food remains, followed by earth (Sand), and the third item was plastic.

Hazardous materials were observed as a component of solid waste. No statistical significant difference in solid waste composition between residential sectors and seasons. Study findings have significant economic prospective in solid waste management particular high percentages of organic components and low density of solid waste.

\section{Acknowledgement}

The authors would like to express their thankful to DAAD for the financial support grant number A/12/99512. Great thankful to all those who were participated effectively in the study activities for their helpful contributions, particularly data collectors, collection and segregation workers, Public Health Authoritarians at administration units and sectors, and members of participated households.

\section{References}

1. Abou-Elseoud N (2008) Waste Management. Arab Forum for Environment and Development.

2. Guisti L (2009) A Review of Waste Management Practices and their Impact on Human Health. Waste Manag J 29: 2227-2239.

3. Tavares G, Zsigraiova Z, Semiao V, Garvalho MG (2009) Optimisation of MSW Collection Routes for Minimum Fuel Consumption Using 3D GIS Modeling. Waste Manag J 29: 1176-1185.

4. Haro K, Ouarma I, Nana B, Bere A, Koulidiati J (2018) Characterization and Potential Recovery of Household Solid Waste in the City of Ouagadougou (Burkina Faso). J Environ Protect 9: 309-324.

5. Moftah W, Markovic D, Moftah O, Nesseef L (2016) Characterization of Household Solid Waste and Management in Tripoli City-Libya. Open J Ecol 6: 435-442.

6. Kernan B, Bakh M, Dickerson K, Lam J, Turaki A (2009) Sudan Transitional Environmental Program Pilot Plastic Recycling Project Final Report, Juba, Sudan.

7. Chandramohan A, Ravichandran C, Sivasankar V (2010) Solid Waste, its Health Impairments and Role of Rag Pickers in Tiruchirappalli City, Tamil Nadu, Southern India. Waste Manag Res J 28: 951-958.

8. Abdullah M, Al-Jenaid S, Zubari W, Al-Ali J (2019) An Integrated Method for the Selection of Optimum Locations for Landfilling Utilizing GIS: A Case Study of the State of Kuwait. J Environ Protect 10: 260-275.

9. Son L, Matsui Y, Trang D, Thanh N (2018) Estimation of the Solid Waste Generation and Recycling Potential of the Hotel Sector: A Case Study in Hue City, Vietnam. J Environ Protect 9: 751-769.

10. Gomez G, Meneses M, Ballinas L, Castells F (2009) Seasonal Characterization of Municipal Solid Waste (MSW) in the City of Chihuahua, Mexico. Waste Manag J 29: 2018-2024.

11. Komilis D, Evangelou A, Giannakis G, lymperis C (2012) Revisiting the Elemental Composition and the Calorific Value of the Organic Fraction of Municipal Solid Wastes. Waste Manag J 32: 372-381.
12. Sango I (2010) Analysis of the solid waste management practices in Chinhoyi: Bridging the Missing Link. Waste Manag J 13: 332-347.

13. Keser S, Duzgun S, Aksoy A (2012) Application of Spatial and NonSpatial Data Analysis in Determination of the Factors that Impact Municipal Solid Waste Generation Rates in Turkey. Waste Manag J 2: 359-371.

14. Turan NG, Coruh S, Akdemir A, Ergun ON (2009) Country Report: Municipal Solid Waste Management Strategies in Turkey. Waste Manag J 29: 465-469.

15. Vuai SAH (2010) Characterization of MSW and Related Waste-Derived Compost in Zanzibar municipality. Waste Manag Res J 28: 177-184.

16. United Nations Environment Program (2005) Integrated Waste Management Scoreboard A Tool to Measure Performance in Municipal Solid Waste Management, UNEP.

17. World Bank (1999) Solid Waste Management in Asia. Urban Development Sector Unit.

18. Batool SA, Nawaz M (2009) Country Report: Municipal Solid Waste Management in Lahore City District, Pakistan. Waste Manag J 29: 1971-1981.

19. Weng YC, Fujiwara T, Matsuoka Y (2010) An Analysis of Municipal Solid Waste Discards in Taiwan Based in Consumption Expenditure and Policy Interventions. Waste Manag Res J 28: 245-255.

20. Yousuf T, Rahman M (2007) Monitoring Quantity and Characteristics of Municipal Solid Waste in Dhaka City. Environ Monit Assess J 11: 135.

21. Daura L, Enaburekhan J, Rufai A (2014) Characteristics and Composition Analysis of Municipal Solid Waste in Kano, Nigeria. Int J Sci Eng Res 5: 972-975.

22. Chowdhury M (2009) Searching Quality Data for Municipal Solid Waste Planning. Waste Manag J 29: 2240-2247.

23. Guermoud N, Ouadjnia F, Abdelmalek F, Taleb F, Addou A (2009) Municipal Solid Waste in Mostaganem City (Western Algeria). Waste Manag 29: 896-902.

24. Sakawi Z (2011) Municipal Solid Waste Management in Malaysia: Solution for Sustainable Waste Management. J Applied Sci Environ Sanit 6: 29-38.

25. WHO (1996) Annex 2.1: Procedure for Solid Waste Generation. Series No.6, World Health Organization. Western Pacific Region.

26. Eisted R, Christensen TH (2011) Characterization of Household Waste in Greenland. Waste Manag J 31: 1461-1466.

27. Haro K, Ouarma I, Nana B, Bere A, Koulidiati J (2018) Characterization and Potential Recovery of Household Solid Waste in the City of Ouagadougou (Burkina Faso). J Environ Protect 9: 309-324.

28. California Integrated Waste Management Board (CIWMB) (2004) Statewide Waste Characterization Study. Publication \#340-04-005.

29. Norbu Dilokwanich S, Uyasatian U, Saguanwong P (2010) Municipal Solid Waste Management in Phuntsholing City, Bhutan. J Environ Asia 3: 111-116.

30. Wang H, He J, Kim Y, Kamata T (2011) Municipal Solid Waste Management in Small Towns: An Economic Analysis Conducted in Yunnan, China. The World Bank Development Research Group Environment and Energy Team. Policy Research Working Paper.

31. Mbande C (2003) Appropriate Approach in Measuring Waste Generation Composition and Density in Developing Areas. J South African Institut Civil Eng 45: 2-10.

32. Passarini F, Vassura I, Monti F, Morselli L, Villani B (2011) Indicators of waste Management Efficiency Related to Different Territorial Conditions. Waste Manag J 3: 785-792.

33. Boer ED, Boer JD, Jaroszynska J, Szpadt R (2012) Monitoring of Municipal Waste Generated in the City of Warsaw. Waste Manag Res J 30: 772-780.

34. Edjabou ME, Moller J, Christensen TH (2012) Solid Waste Characterization in Ketao a Rural Town in Togo, West Africa. Waste Manag Res J 30: 745-749. 
Citation: Mohamed Elzaki AA, Elhassan BM (2019) Quantification and Characterization of Solid Waste in Alkalakla Administrative Unit, Khartoum State-Sudan. Int J Waste Resour 9: 364. doi:10.35248/2252-5211.19.9.364

Page 6 of 6

35. Yi S, Yoo KY, Hanaki K (2010) Characteristics of MSW and Heat Energy Recovery Between Residential and Commercial Areas in Seoul. Waste Manag J 31: 595-602.

36. Al-Khatib IA, Arafat HA (2010) A Review of Residential Solid Waste Management in the Occupied Palestinian Territory: A Window for Improvement? Waste Manag Res J 28: 481-488.

37. Japan International Cooperation Agency (JICA) (2005) The Study on the Solid Waste Management in Dhaka City. Main Report, Pacific Consultants International Yachiyo Engineering Co., Ltd ( Vol 2).

38. Hazra T, Goel S (2009) Country Report Solid Waste Management in Kolkata, India: Practices and challenges. Waste Manag J 29: 470-478.

39. Abdul J (2010) Sustain able Development in Malaysia: A Case Study on Household Waste Management. J Sustain Develop 3: 91-10.
40. Moghadam AMR, Mokhtarani A, Mokhtarani B (2009) Municipal Solid Waste Management in Rasht City, Iran. Waste Manag J 29: 485-489.

41. Moqsud MA (2010) Composting Barrel for Sustainable Organic, Waste Management in Bangladesh. Waste Management, Er Sunil Kumar (Eds), Chapter 5, InTech 77.

42. Liao W, Tingquan P, Chuan H, Hui Y (2009) Management of Municipal Solid Waste in the Three Gorges Region. Waste Manag J 29: 2203-2208.

43. Parrot L, Sotamenou J, Dia BK (2009) Municipal Solid Waste Management in Africa: Strategies and Livelihoods in yaoundé, Cameroon. Waste Manag J 29: 986-995. 